ROCZNIKI TEOLOGICZNE

Volume LXV, issue 9 - 2018

Englis h version

DOI: http://dx.doi.org/10.18290/rt.2018.65.9-4en

REV. PAWEŁ BORTO

\title{
THE LUBLIN SCHOOL OF FUNDAMENTAL THEOLOGY'S UNDERSTANDING OF DIVINE REVELATION
}

\begin{abstract}
This article discusses how Divine Revelation is understood at the Lublin School of Fundamental Theology. After presenting the significance of the reflection on the subject of Revelation, the article presents the most important characteristics of our reflection on this subject typical of the group of theologians associated with John Paul II Catholic University of Lublin. This includes their personalistic understanding of Divine Revelation, the meaning of Divine Revelation in the theological interpretation of religion and their comprehension of Revelation's credibility.
\end{abstract}

Keywords: fundamental theology; the Lublin School of Fundamental Theology; Revelation.

1918 was a special year for the academic community of John Paul II Catholic University of Lublin. Today, the $100^{\text {th }}$ year anniversary of the existence of this university, an institution created at the time of the revival of Poland's statehood. This is a good opportunity to summarize, outline perspectives, and try to make a certain account of matters. The article recapitulates and undertakes one aspect of our reflection in the field of fundamental theology.

The mentioned theological discipline was a lecture topic at the Faculty of Theology of the Catholic University of Lublin from its very beginning. ${ }^{1}$ Divine Revelation was also one of the issues taken up in the study of fundamental theology.

In this article, we will get to know the most important features characterizing our reflection on divine revelation in Lublin's academic environment. First, the importance of such a reflection for fundamental theology

Rev. Dr. Pawet Borto is an adjunct of the Chair of Fundamental Christology and Ecclesiology at the Institute of Fundamental Theology at the Catholic University of Lublin; mailing address: ul. Jana Pawła II no 7, 25-025 Kielce; e-mail: pabo@onet.pl

${ }^{1}$ Krzysztof KaUCHA, "Wiarygodność i wiara w ujęciu lubelskiej szkoły teologii fundamentalnej," in Wiara a wiarygodność, ed. Damian Wąsek (Kraków: Wydawnictwo Naukowe UPJPII, 2014), 51. 
will be briefly explained, and then we will point to the areas and people undertaking this reflection and creating Lublin's school of fundamental theology. The next sections of the article will explain how the category of divine revelation is perceived in the above academic environment, its significance in theological and religious reflection and how the credibility of revelation itself is understood.

\section{THE SIGNIFICANCE OF REFLECTING ON THE CONCEPT OF DIVINE REVELATION}

In the history of reflecting on divine revelation, one can see a clear boundary. Up until modern times, the idea of divine revelation was not questioned or subject to a more detailed theological reflection. In the period preceding modernity, there were views that challenged particular revealed truths, but the very idea and concept of revelation were not questioned.

The situation changed with the arrival of modernity, especially with the appearance of the theses proclaimed by authors associated with modernism, who questioned the very possibility of divine revelation. From that moment on, reflection on the notion of revelation would become one of the main themes undertaken within the scope of philosophical and theological thoughts. This is how the Treatise on Revelation was formed, which is an essential part of fundamental theology. It is the fruit of modern disputes over one of the most important concepts. ${ }^{2}$

The Second Vatican Council's acceptance of the Dogmatic Constitution Dei Verbum is a special expression of the Church's awareness of the importance of reflecting on this concept, and simultaneously reminds us that reflecting on divine revelation matured in the Church only in modern times. After all, Dei Verbum was the first document in the history of the Ecumenical Councils in which the issue of revelation was presented in a systematic way. ${ }^{3}$

\footnotetext{
${ }^{2}$ Max SeCKLER, "Il concetto di rivelazione," in Corso di teologia fondametale. 2. Trattato sulla rivelazione, ed. Walter Kern, Hermann J. Pottmeyer, Max Seckler (Brescia: Queriniana, 1990), 67; Marian RuSECKI, “Objawienie Boże," in Leksykon Teologii Fundamentalnej, ed. Marian Rusecki et al. (Lublin-Kraków: Wydawnictwo M, 2002), 859; Giuseppe LoRIzIO, "Teologia della rivelazione ed elementi di cristologia fondamentale," in Teologia fondamentale. 2. Fondamenti, ed. Giuseppe Lorizio (Roma: Città Nuova, 2005), 7-8.

${ }^{3}$ Helmut HopING, "Theologischer Kommentar zur Dogmatischen Konstituzion über die göttlische Offenbarung," in Herders theologischer Kommentar zum Zweiten Vatikanischen Konzil. 3, ed. P. Hünermann et al. (Freiburg-Basel-Wien: Herder, 2009), 701.
} 
The concept of divine revelation is a key issue for modern theology. ${ }^{4}$ However, this does not mean that all authors accept it without any problems. Let's recall the most important accusations to see what significance and problems may lie in this seemingly obvious discovery that the concept of revelation is of fundamental importance for theology. The concept of revelation is accused of not being biblical, or rather that it is a mythological or ideological concept, and expresses something arbitrary in relation to Christianity; that its widespread use has resulted in the depreciation of its importance and its content has been nullified, so that one can speak of a specific "inflation" of the concept of revelation; that contemporary culture uses this concept only in a metaphorical sense, and it is received with skepticism in relation to the dominant striving for objectivity and science. ${ }^{5}$ These are only the most important accusations.

Yet, it seems that although the concept of revelation has its limits, it has already acquired a clearly defined content in theological reflection. This concept expresses the fact of salvation revealed by God, his saving will towards man that invites men to be in communion with God. The accusation concerns its lack of precise contents, meaning that the concept of divine revelation is often equated with concepts such as "God's Word," "salvation history," "the Gospel" or "communication / participation in the divine life," and these do not have to disqualify it in this case. A certain "openness" and the widest possible understanding of divine revelation are necessary in order to not reduce this reality to a merely cognitive dimension and not limit ourselves in our reflection on God's disclosure in history to only the freedom and grace of God's action. ${ }^{6}$

It should be added that in theological reflection, the concept of divine revelation can be read in two ways, which was first noticed by R.L. Hart, and therefore it can be understood as the foundation and a separate category. ${ }^{7}$ On the one hand, the notion of divine revelation expresses the truth

\footnotetext{
${ }^{4}$ Karl Rahner states that this is the most basic concept for Christianity; cf. Schriften zur Theologie, Band XIV. Im Sorge um die Kirche (Zürich-Einsiedeln-Köln: Benzinger Verlag, 1980), 56.

${ }^{5}$ SECKLER, "Il concetto di rivelazione," 67-68. The most important difficulties raised in contemporary theology in relation to the concept of Revelation are discussed by Carlo Greco, Rivelazione di Dio e ragioni della fede: un percorso di teologia fondamentale (Cinisello Balsamo: Edizioni San Paolo, 2012), 43-47.

${ }^{6}$ Cf. also Giuseppe TAnzella-NitTI, Teologia della credibilità: la teologia fondamentale e la sua dimensione di apologia (Roma: Città Nuova, 2015), 262.

${ }^{7}$ Ray L. HART, Unfinished Man and the Imagination. Toward an Ontology and a Rhetoric of Revelation (New York, 1968).
} 
about what constitutes the basis for all theological contents (it is the basis of all theology, meaning every other issue undertaken in theological reflection). On the other hand, this concept contains one exceptional topic, meaning God's disclosure in the history and works of mankind. ${ }^{8}$

\section{REFLEXIONS ON DIVINE REVELATION IN THE LUBLIN SCHOOL OF FUNDAMENTAL THEOLOGY}

In an article published in 2014 devoted to the issue of the credibility of fundamental theology at the Lublin school, Rev. K. Kaucha presented arguments that the existence of the Lublin School of Fundamental Theology starting from the activity and creativity of Rev. E. Kopeć and that its formation is basically related to the post-conciliar period. ${ }^{9}$ In this report, these findings are accepted as the starting point in searching for an answer to the question about the characteristics of the school's reflections on divine revelation in the Lublin center of fundamental theology.

The concept of divine revelation, since the breakthrough conciliar council, was the subject of reflection by representatives of the Lublin center of fundamental theology. The first author undertaking this subject matter was Rev. E. Kopeć, who in the introductory volume of Rev. W. Granat's Catholic dogmatics wrote a chapter devoted to the concept of divine revelation. ${ }^{10}$ This publication also testifies that at the Lublin school of fundamental theology, reflection on the notion of divine revelation did not begin as a response to the Second Vatican Council's Constitution Dei Verbum, but matured in close dialogue with the thoughts of Western theologians. ${ }^{11}$

Apart from Rev. E. Kopeć, who published more works on his reflections on the notion of Divine revelation, first and foremost, two representatives of the Lublin center of fundamental theology should be mentioned, who refined our understanding of divine revelation. The first is Rev. M. Rusecki. He left

\footnotetext{
${ }^{8} \mathrm{M}$. Seckler draws attention to the two above-mentioned aspects of meaning present in the notion of revelation, who however limits the understanding of divine revelation to various experiences in the "Biblical-Christian" Word (cf. SECKLER, "Il concetto di rivelazione," 80), which, from the perspective of modern theology, revelation can be contested.

${ }^{9}$ Cf. KAUCHA, "Wiarygodność i wiara w ujęciu lubelskiej szkoły teologii fundamentalnej," 51-60.

${ }^{10}$ Edward Kopeć, "Pojęcie objawienia Bożego," in Dogmatyka katolicka: tom wstępny, ed. Wincenty Granat (Lublin: Towarzystwo Naukowe KUL, 1965), 95-115.

${ }^{11}$ Here we can mention several authors: F. Arnold, J. Baillie, W. Bulst, R. Guardini, R. Latourelle, C. Lercher, J.B. Lotz, H. de Lubac, J. Mouroux, K. Rahner, H. Schlier.
} 
a number of important publications included in the Lexicon of Fundamental Theology and the Catholic Encyclopedia, and the culmination of his reflections on divine revelation is his monumental Treatise on Revelation, a work counting 837 pages. The second author who in his publications undertook a reflection on the concept of divine revelation is I.S. Ledwon OFM, who coauthored entries with Rev. M. Rusecki in the Lexicon of Fundamental Theology and is the author of other articles along with Rev. J. Mastej. ${ }^{12}$

Our reflection on the issue of divine revelation at the Lublin center also includes a theological reflection on religions in this context. The first major publications in this field were by Rev. R. Łukaszyk, ${ }^{13}$ and this dimension of reflecting on divine revelation, also present in other religions, was later undertaken by Rev. M. Rusecki and Fr. I.S. Ledwoń. ${ }^{14}$

The third aspect taking into account the reflection on the concept of divine revelation among the Lublin authors is related to their similarity with the thoughts of other theologians who have been dealing with this topic. Publications by the following authors should be indicated here: Rev. M. Rusecki, ${ }^{15}$ Fr. I.S. Ledwoń ${ }^{16}$ and Rev. P. Borto. ${ }^{17}$

\footnotetext{
12 Jacenty MASTEJ, "Osobowy charakter objawionego przedmiotu wiary chrześcijańskiej," Resovia Sacra 7 (2000), 45-71.

${ }^{13}$ Primarily in the articles: ŁUKASZYK, "Religie niechrześcijańskie w ocenie teologii współczesnej," Ateneum Kapłańskie 73 (1969), 247-259; Romuald ŁUKASZYK, "Objawienie kosmiczne jako pierwszy etap objawienia się Boga," Roczniki Teologiczno-Kanoniczne 24 (1977): 141-153.

${ }^{14}$ Marian RuSECKI, Istota i geneza religii (Warsaw: Verbinum, 1989); IDEM, "Elementy zbawcze w religiach pozachrześcijańskich," in Odkupienie a dialog międzyreligijny. Materiały z sympozjum w Obrze, 20-21 kwietnia 1998 r., ed. Wojciech Kluj (Poznań: Uniwersytet im. Adama Mickiewicza, 1999), 21-61; IDEM, "Pojęcie Objawienia Bożego w religiach," Roczniki Teologiczne 46 (1999): 13-27; IDEM, "Objawieniowa geneza religii," in Plenitudo legis dilectio. Ksiega pamiatkowa dedykowana prof. dr. hab. Bronisławowi W. Zubertowi OFM z okazji 65. Rocznicy urodzin (Lublin: Wydawnictwo KUL, 2000), 789-799; IDEM, Traktat o religii (Warsaw: Verbinum, 2007); Ireneusz S. LEDWoŃ, ,... I nie ma w żadnym innym zbawienia.” Wyjątkowy charakter chrześcijaństwa w teologii posoborowej (Lublin: Wydawnictwo KUL, 2012), IDEM, "Objawienie jako kryterium prawdziwości religii w świetle teologii religii," Zborník sociologických a religionistických štúdií 2 (2012): 59-80.

${ }^{15}$ Marian RUSECKI, "Jeana Mouroux elementy personalistycznej koncepcji Objawienia," Roczniki Teologiczne 47, no 9 (2000): 13-29.

${ }^{16}$ Ireneusz S. LEDwoń, Objawienie chrześcijańskie i jego wiarygodność wedtug René Latourelle'a (Lublin: Polihymnia, 1996); IDEM, “Koncepcja objawienia według René Latourelle’a," in Objawienie Boże w interpretacji wspótczesnych teologów, ed. Bogusław Kochaniewicz (Poznań: Uniwersytet im. Adama Mickiewicza, 2010), 31-42.

${ }^{17}$ Paweł Borto, Objawienie a Tradycja w teologii Yves'a Congara i Henri de Lubaca (Kielce: Jedność, 2007); IDEM, "Yves'a Congara rozumienie Objawienia," in Objawienie Boże w interpretacji wspótczesnych teologów, 131-148.
} 
It should be added that, although not all authors are included among the creators or continuators of the ideas at Lublin's school of fundamental theology undertook a reflection on the concept of divine revelation, their publications show that the basis of other topics covered in fundamental theology include the method of understanding divine revelation and that they accept similar assumptions according to their understanding.

\section{UNDERSTANDING DIVINE REVELATION AT THE LUBLIN SCHOOL OF FUNDAMENTAL THEOLOGY}

The most appropriate and the general term reflecting our understanding of Divine Revelation at the Lublin school of fundamental theology is the personalistic concept. ${ }^{18}$ This term refers to the systematization of various ways of understanding divine revelation in contemporary theology according to Rev. M. Rusecki. In his analyzes, the reflections of various modern authors present several different concepts of the idea of divine revelation: intellectual, salvation history, personalistic, transcendental-anthropological, immanent, sign and symbolic. ${ }^{19}$

It is the personalistic concept, referring to the personalism developed in Lublin's academic community and the philosophical thoughts at the Catholic University of Lublin, that best seem to define the way of reflection on divine revelation according to the representatives of the Lublin school of fundamental theology. This view of the reality of divine revelation began with Rev. E. Kopeć and was developed by Rev. M. Rusecki. ${ }^{20}$

Admittedly, among the publications summarizing the academic reflection on Rev. M. Rusecki's notion of divine revelation, one can find those in which the symbolic concept is referred to, ${ }^{21}$ yet we should probably not see

\footnotetext{
${ }^{18}$ For more on the topic of personalistic theology cf.: Krzysztof KAUCHA, "Teologia personalistyczna," in Koncepcje teologii katolickiej, ed. Marek Chojnacki et al. (Kraków: Salwator, 2013), 87-110.

${ }^{19}$ Marian Rusecki, I.S. Ledwoń, “Objawienie Boże,” in Leksykon Teologii Fundamentalnej, ed. Marian Rusecki et al. (Lublin-Kraków: Wydawnictwo M, 2002), 863 (from now on LTF will be the abbreviation used for the Leksykonu Teologii Fundamentalnej).

${ }^{20}$ Cf. Marian RUSECKI, "Elementy personalistycznej teologii fundamentalnej w ujęciu Edwarda Kopcia," Roczniki Teologiczne 32, no 9 (1985): 23-37; Krzysztof Guzowski, "Personalizm Objawienia i wiary w ujęciu Ks. prof. Mariana Ruseckiego," in Scio cui credidi. Księga pamiatkowa ku czci Księdza Profesora Mariana Ruseckiego w 65. rocznicę urodzin, ed. Ireneusz S. Ledwoń et al. (Lublin: Wydawnictwo KUL, 2007), 76.

${ }^{21}$ Jacenty MASTEJ, “Znakowa koncepcja Objawienia ks. profesora Mariana Ruseckiego,” in Objawienie Boże w interpretacji wspótczesnych teologów, 77-86.
} 
a contradiction here. Rev. M. Rusecki himself did not understand this in a negative way. He pointed out that his reading of divine revelation from a historical and symbolic perspective harmonized well with the personalistic concept, and this was the way others also evaluated it. ${ }^{22}$

It seems that some clarification can be made in this regard. The statement that divine revelation is understood in a personalistic way means that both the subject of revelation (God), its object (the fullness of revelation in Jesus Christ) and the addressee (every person) have a personal characteristic. Revelation is therefore carried out in the dimension of a personal meeting between God and man. The goal of divine revelation is man's participation in the mystery of the community of God's people. Thus, it is rightly pointed out that the personalistic dimension is inseparably inscribed into the process of divine revelation, present throughout all of its earthly history and is also characterized by its fulfillment.

On the other hand, the emphasis placed on the symbolic or historical dimension in the process of divine revelation draws attention first and foremost to the way it was implemented in the earthly context. Thus, the personalistic approach is broader and also takes into account the dimension of divine revelation in the eschaton. For a reflection systemizing various ways of reflecting on divine revelation aimed at capturing the leading ideas characterizing the events of divine revelation, making a distinction between the personalistic, salvation history or symbolic concepts is appropriate. It can be said, however, that the Lublin school's fundamental theological thoughts are characterized by a personalistic concept, which includes salvation history and symbolic aspects.

The personalistic understanding of revelation does not exclude, but rather presupposes, that in the earthly context, meaning establishing a relationship between God and man, is symbolic and historical. Ultimately, divine revelation will be a meeting in which we will get to know God no longer as in a mirror, but face to face (cf. 1 Cor 13:12), no longer through symbols and historical limitations, but in full personal communion.

\footnotetext{
${ }^{22}$ Tadeusz DolA, "Personalistyczna koncepcja teologii fundamentalnej ks. Mariana Ruseckiego," in Scio cui credidi, 63; Krzysztof Guzowski, "Personalizm Objawienia i wiary w ujęciu ks. prof. Mariana Ruseckiego," in Scio cui credidi, 75-81.
} 


\section{REFLECTIONS ON THE CONCEPT OF DIVINE REVELATION IN RELATION TO THEOLOGY OF RELIGION}

The issue of divine revelation in fundamental theology through the mediation of created reality is one of the themes that has been taken into account from the beginning in the reflections of representatives of the Lublin school of fundamental theology. Rev. E. Kopeć gave a classical account and was still writing about the so-called natural revelation. ${ }^{23}$

Subsequent representatives of this school critically referred to such an approach that up till then characterized fundamental theology's reflections. They emphasized that the above expression is characterized by an internal contradiction, because God's grace is necessary for the process of divine revelation. Although God reveals Himself through what is created and in creation itself, revelation is also accompanied by some supernatural dimension. ${ }^{24}$

Reflections on the issue of revelation in creatures and through creation are present at the Lublin school of fundamental theology, and this topic is taken into account in our reflections on the theology of religion. Rev. R. Łukaszyk initiated it, ${ }^{25}$ and it was especially expanded by Rev. M. Rusecki and Fr. I.S. Ledwoń. In their publications, they emphasized that reducing the genesis of non-Christian religions to the level of nature is wrong. Authentic religions arose through divine revelation. This is obvious in relation to Christianity, but also the origins of non-Christian religions should be sought in divine revelation present in creation and creatures. ${ }^{26}$

It is impossible to briefly quote here all the arguments behind this statement. It is the fruit of reflection on biblical data, the results of studies on philosophical anthropology, philosophy and the theology of religion, including attempts to incorporate the axiom on the universal salvific will of God with the concept of revelation. ${ }^{27}$ However, an important conclusion follows.

\footnotetext{
${ }^{23}$ Edward Kopeć, Teologia fundamentalna (Lublin: KUL, 1976), 46.

${ }^{24}$ Romuald ŁUKASZYK, "Objawienie kosmiczne jako pierwszy etap objawienia się Boga," Roczniki Teologiczno-Kanoniczne 24 (1977): 255; Marian RusECKI, Traktat o Objawieniu (Kraków: Wydawnictwo Księży Sercanów, 2007), 158.

${ }^{25}$ ŁUKASZYK, "Objawienie kosmiczne."

${ }^{26}$ Cf. Marian RUSECKI, Istota i geneza religii, (Lublin-Sandomierz: Wydawnictwo Diecezjalne, 1997), 204-221; IDEM, "Geneza religii," in LTF, 431-440; IDEM, "Objawienie Boże. II. Objawienie przez stworzenia i w stworzeniach,” in LTF, 863-865; LEDwoŃ, ,... i nie ma w żadnym innym zbawienia," 461-497.

${ }^{27}$ The authors refer to a whole range of biblical texts about the appearance of God in the world (cf. Job 36-39, Ps 19; 136; Wis 13:1-9, Acts 17:24-29, Rom 1:20-25) but also that man himself is made in the image of God (cf. Gen 1:26f, 2:7) and experiences the voice of conscience
} 
According to representatives of the Lublin school of fundamental theology, the concept of divine revelation should not be "limited" to the biblical economy, but it contains a broader meaning and states that God has graciously revealed himself to all people in creatures and through creation. ${ }^{28}$

In this way, in the Lublin school of fundamental theology, the category of divine revelation was pointed out as the proper way to resolve some contradictions found at the heart of theology of religion, where on the one hand it was claimed that "the seeds and shoots of the Word," reflections on God's eternal Truth (cf. Nostra Aetate 2), are present in various religions, and on the other, divine revelation was limited only to the economics of the Old and New Testaments.

Let us add that the assumption that divine revelation through creation and creatures is the foundation of non-Christian religions is not an expression of religious pluralism and does not deny the unique character of Christianity, but while protecting its uniqueness, also reveals a common dimension existing between Christianity and other religions.

\section{REFLECTION ON THE CONCEPT OF DIVINE REVELATION ON THE LEVEL OF CREDIBILITY}

Understanding divine revelation in personalistic terms for the representatives of the Lublin school of fundamental theology means that a person is a superior value in relation to other created beings and that this personal category is a reference point in getting to know God. In personalism, interpersonal cognition appears to be a higher order cognition than factual cognition. ${ }^{29}$

The above statements stand at the foundation of the belief that divine revelation is a reality that cannot be proven in the way in which impersonal truths are proved. That is why the Lublin school of fundamental theology speaks of justification, not proof. The credibility of divine revelation, which is the essence of fundamental theology, appears not as a result of attaining the obvious, but is

(cf. Rom 2:14). Moreover, referring to the works of H. de Lubac, they criticize the notion of pure nature as unbiblical in the theory of "natural revelation" and point to theological topics that allow us to see the world as the place where God's grace works (the Christian dimension of creation, the validity of the covenant with Noah, etc.), including citing data from phenomenological and religious analyzes in support of this thesis.

${ }^{28}$ Ireneusz S. LEDwoŃ, "Problematyka teologicznoreligijna w myśli Rev. Mariana Ruseckiego," in Scio cui credidi, 164-165.

${ }^{29}$ Guzowski, "Personalizm Objawienia i wiary," 76. 
due to reasons and motives that encourage the faith, meaning thanks to moral certainty. The act of faith is understood here as an act having a rational basis, but also an act demanding a free-will decision, thus being an act that is not associated with "coercion" in the intellectual sphere. ${ }^{30}$

The comprehensive Treatise on the Reliability of Christianity by Rev. M. Rusecki is the best summary of how he argues in favor of the faith in Christ and in the Church within the Lublin school of fundamental theology. It contains 15 arguments, both classical and long-standing in the fundamental theology's reflections, such as the resurrectionist argument, scripturalism, the miracles of Jesus, as well as the original arguments developed in basic metaphysical categories (verdative, bonative and calonistic arguments), Christian values (martyrological and praxeological arguments) or those related to man's self-realization (agapetological, sperantive, culture-forming, personalistic, axiological arguments) and the comparison of Christianity with other religions (comparative argument). ${ }^{31}$

The multiplicity of the mentioned arguments is also an expression of the conviction of the representatives of the Lublin school of fundamental theology that the arguments for the credibility of divine revelation are something that must be constantly undertaken due to the changing context of faith and its recipient. ${ }^{32} \mathrm{~A}$ personalistic understanding of the credibility of revelation requires that attention should be paid not only to the source and subject of revelation, but also to its addressee, and also to keep in mind that divine revelation gives us access not just to some contents but to live contact with a personal God.

Giuseppe Ruggieri critically assessed the idea of theologically considering some concepts to be fundamental in nature. He justified his criticism by the fact that in theology, it is possible to give a privileged place to certain concepts due to a specific historical context, but essentially, Christianity should not be based on concepts, because Christian experience and reflection on something is the result of a living reference, reasoning with the help of

\footnotetext{
${ }^{30}$ Marian RUSECKI, “Argumentacja w teologii fundamentalnej," in LTF, 109-110; IDEM, Traktat o wiarygodności chrześcijaństwa. Dlaczego wierzyć Chrystusowi? (Lublin: TN KUL, 2010), 12-13.

${ }^{31}$ We should add that in one of the arguments found in Traktacie o wiarygodności chrześcijaństwa is by the author Rev. K. Kaucha and that some of remaining arguments were also created by K. Kaucha and I.S. Ledwoń for the Leksykon Teologii Fundamentalnej.

${ }^{32}$ RUSECKI, "Argumentacja w teologii fundamentalnej," 109.
} 
concepts "in the sphere of adoration and obedience to the Truth captured in Christ's happening." 33

It seems that the personalistic understanding of divine revelation helps us to avoid this danger. Rev. M. Rusecki expressed this well in his Treatise on Revelation, where he stressed that divine revelation for fundamental theology is fully achieved in Jesus Christ. This is not only a fact from the past, but a reality still alive and timely, always transmitted and available in the Church. ${ }^{34}$

For the Lublin school of fundamental theology, it is also important that this idea be characterized by the discipline's methodological coherence, meaning practicing it in close connection with proving the Christian credibility of revelation performed in Jesus Christ and transmitted in the Church. We should also care that individual arguments for the credibility of this revelation be presented in a most articulate and critical way.

Let us add that the close connection between our reflection on religions, the issues associated with divine revelation and the attempt to reconcile the uniqueness of divine revelation with Christ and the revelatory understanding of non-Christian religions shows that the Lublin school of fundamental theology is an environment that has developed original theological and religious ideas where the theology of religion consistently refers to questions on revelation that are relevant to all theologies.

The last important comment relates to the way in which our reflection on divine revelation is formed within the Lublin school of fundamental theology. Although the above issues seem to suggest that this is a theoretical reflection seeking to develop a coherent system within a strictly defined discipline carried out on the basis of deduction (thanks to Rev. M. Rusecki, there is a comprehensive work on the methodological foundations of fundamental theology), ${ }^{35}$ however, the road leading to understanding divine revelation was different here. It is a reflection on divine revelation characterized by inductive reasoning, and therefore based on the facts of divine revelation and its specific moments, confirmed by the history of the chosen people and Christianity. From this, we draw the right conclusions and try to

\footnotetext{
${ }^{33}$ Giuseppe RUGGIERI, "La problematica della rivelazione come "concetto fondamentale" del cristianesimo," in La teologia della Rivelazione: Atti del III corso di aggiornamento per docenti di teologia dogmatica (Roma, 4-5 gennaio 1993), ed. D. Valentini (Padova: Messagero, 1996), 104.

${ }^{34}$ RUSECKI, Traktat o Objawieniu, 10.

${ }^{35}$ Cf. also Marian RuSECKI, Wiarygodność chrześcijaństwa: z teorii teologii fundamentalnej, (Lublin 1994).
} 
shed light on all the areas of fundamental theological reflection. ${ }^{36}$ Rev. M. Rusecki's Treatise on Revelation is the best example of this.

\section{BIBLIOGRAPHY}

Borto, Paweł. Objawienie a Tradycja w teologii Yves'a Congara i Henri de Lubaca [Revelation and Tradition in the Theology of Yves Congar and Henri de Lubac]. Kielce: Jedność, 2007.

Borto, Paweł. "Yves'a Congara rozumienie Objawienia.” In Objawienie Boże w interpretacji wspótczesnych teologów ["Yves Congar's Understanding of Revelation." In: Divine Revelation in the Interpretation of Modern Theologians], edited by Bogusław Kochaniewicz, 131148. Poznań: University of Adama Mickiewicza, 2010.

DolA, Tadeusz. "Personalistyczna koncepcja teologii fundamentalnej Ks. Mariana Ruseckiego." In Scio cui credidi. Księga pamiątkowa ku czci Księdza Profesora Mariana Ruseckiego w 65. rocznice urodzin ["The Personalistic Concept of Fundamental Theology by Rev. Marian Rusecki." In: Scio cui credidi. A Memorial Book in Honor of Professor Marian Rusecki on his $65^{\text {th }}$ Birthday], edited by Ireneusz S. Ledwoń, Krzysztof Kaucha, Zbigniew Krzyszowski, Jacenty Mastej, Andrzej Pietrzak, 59-67. Lublin: Wydawnictwo KUL, 2007.

GRECO, Carlo. Rivelazione di Dio e ragioni della fede: un percorso di teologia fondamentale. Cinisello Balsamo: San Paolo, 2012.

GuzowsKi, Krzysztof. "Personalizm Objawienia i wiary w ujęciu Ks. prof. Mariana Ruseckiego.” In Scio cui credidi. Księga pamiątkowa ku czci Księdza Profesora Mariana Ruseckiego w 65. rocznice urodzin ["Personalism of Revelation and Faith in Rev. Prof. Marian Rusecki." In: Scio cui credidi. A Memorial Book in Honor of Professor Marian Rusecki on his $65^{\text {th }}$ Birthday], edited by Ed. Ireneusz S. Ledwoń, Krzysztof Kaucha, Zbigniew Krzyszowski, Jacenty Mastej, Andrzej Pietrzak, 75-81. Lublin: Wydawnictwo KUL, 2007.

HART, Ray L. Unfinished Man and the Imagination. Toward an Ontology and a Rhetoric of Revelation. New York, 1968.

HopING, Helmut. "Theologischer Kommentar zur Dogmatischen Konstituzion über die göttlische Offenbarung." In Herders theologischer Kommentar zum Zweiten Vatikanischen Konzil, edited by Peter Hünermann, Bernd J. Hilberath, 695-831. Freiburg-Basel-Wien: Herder, 2009.

KAUCHA, Krzysztof. "Teologia personalistyczna." In Koncepcje teologii katolickiej ["Personalistic Theology." In: Concepts of Catholic Theology], edited by Marek Chojnacki, Józef Morawa, Andrzej A. Napiórkowski, 87-110. Kraków: Salwator, 2013.

KAUCHA, Krzysztof. "Wiarygodność i wiara w ujęciu lubelskiej szkoły teologii fundamentalnej." In Wiara a wiarygodność ["Credibility and Faith in the Concept of the Lublin School of Fundamental Theology.” In: Faith and Credibility], edited by Damian Wąsek, 49-85. Kraków: Wydawnictwo Naukowe UPJPII, 2014.

Kopeć, Edward. "Pojęcie objawienia Bożego.” In Dogmatyka katolicka: tom wstępny ["The concept of divine revelation." In: Catholic Dogmatics: Introductory Volume], edited by Wincenty Granat, 95-115. Lublin: TN KUL, 1965.

\footnotetext{
${ }^{36}$ According to C. Greco, such a feature of our reflection on divine revelation frees this reflection from the accusation of creating artificial categories, cf. GRECO, Rivelazione di Dio e ragioni della fede, 46.
} 
KoPeć, Edward. Teologia fundamentalna [Fundamental Theology]. Lublin: KUL, 1976.

LEDwoŃ, Ireneusz S. „... i nie ma w żadnym innym zbawienia”. Wyjątkowy charakter chrześcijaństwa w teologii posoborowej [“... and There is no Salvation in Anyone Else.” The Unique Character of Christianity in Post-Conciliar Theology]. Lublin: KUL, 2006.

LEDwoń, Ireneusz S. “Koncepcja objawienia według René Latourelle’a.” In Objawienie Boże w interpretacji wspótczesnych teologów ["The Concept of Revelation according to René Latourelle." In: Revelation of God in the Interpretation of Contemporary Theologians], edited by Bogusław Kochaniewicz, 31-42. Poznań: Uniwersytet im. Adama Mickiewicza, 2010.

LEDWoŃ, Ireneusz S. Objawienie chrześcijańskie i jego wiarygodność wedtug René Latourelle'a [Christian Revelation and its Credibility according to René Latourelle]. Lublin: Polihymnia, 1996.

LEDwoŃ, Ireneusz S. "Objawienie jako kryterium prawdziwości religii w świetle teologii religii” ["Revelation as a Criterion of the Truth of Religion in the Light of the Theology of Religion”]. Zborník sociologických a religionistických štúdií 2 (2012): 59-80.

LEDWOŃ, Ireneusz S. "Problematyka teologicznoreligijna w myśli Rev. Mariana Ruseckiego" ["Theological and Religious Issues in the Thoughts of Rev. Marian Rusecki"]. In Scio cui credidi. Księga pamiątkowa ku czci Księdza Profesora Mariana Ruseckiego w 65. rocznice urodzin [Scio cui credidi. A Memorial Book in Honor of Professor Marian Rusecki on his $65^{\text {th }}$ Birthday], edited by Ireneusz S. Ledwoń, Krzysztof Kaucha, Zbigniew Krzyszowski, Jacenty Mastej, Andrzej Pietrzak, 157-170. Lublin: Wydawnictwo KUL, 2007.

LORIZIO, Giuseppe. "Teologia della rivelazione ed elementi di cristologia fondamentale." In Teologia fondamentale. 2. Fondamenti, edited by Giuseppe Lorizio, 7-234. Rome: Città Nuova, 2005.

ŁUKASZYK, Romuald. "Religie niechrześcijańskie w ocenie teologii współczesnej" ["Non-Christian Religions in the Evaluation of Contemporary Theology"]. Ateneum Kaptańskie 73 (1969): 247-259.

ŁUKASZYK, Romuald. "Objawienie kosmiczne jako pierwszy etap objawienia się Boga" ["Cosmic Revelation as the First Stage of God's Revelation"]. Roczniki Teologiczno-Kanoniczne 24 (1977): 141-153.

MASTEJ, Jacenty. "Osobowy charakter objawionego przedmiotu wiary chrześcijańskiej” [“The Personal Nature of the Revealed Subject of the Christian Faith"]. Resovia Sacra 7 (2000): 45-71.

MAsteJ, Jacenty. “Znakowa koncepcja Objawienia Ks. profesora Mariana Ruseckiego.” In Objawienie Boże w interpretacji wspótczesnych teologów ["The Sign Concept of Revelation by Rev. Professor Marian Rusecki." In: Divine Revelation in the Interpretation of Modern Theologians], edited by Bogusław Kochaniewicz, 77-86. Poznań: Uniwersytet Adama Mickiewicza, 2010.

RAHNER, Karl. Schriften zur Theologie, Band XIV. Im Sorge um die Kirche. Zürich-EinsiedelnKöln: Benzinger, 1980.

RUGGIERI, Giuseppe. "La problematica della rivelazione come «concetto fondamentale» del cristianesimo." In La teologia della Rivelazione, edited by Donato Valentini, 81-105. Padova: Messaggero, 1996.

RUSECKI, Marian. “Argumentacja w teologii fundamentalnej.” In Leksykon Teologii Fundamentalnej [“Argumentation in Fundamental Theology." In: Lexicon of Fundamental Theology], edited by Marian Rusecki, Krzysztof Kaucha, Ireneusz S. Ledwoń, Jacenty Mastej, 109-110. Lublin-Krakow: Wydawnictwo M, 2002. 
RUSECKI, Marian. "Elementy personalistycznej teologii fundamentalnej w ujęciu Edwarda Kopcia" ["Elements of Personalistic Fundamental Theology according to Edward Kopeć"]. Roczniki Teologiczne 32, no 9 (1985): 23-37.

RUSECKI, Marian. "Elementy zbawcze w religiach pozachrześcijańskich.” In Odkupienie a dialog międzyreligijny. Materiaty z sympozjum w Obrze, 20-21 kwietnia 1998 r. ["Salvation Elements in non-Christian Religions." In: Redemption and Interreligious Dialogue. Materials from the Symposium in Obra, April 20-21, 1998], edited by Wojciech Kluj, 21-61. Poznań: Uniwersytet im. Adama Mickiewicza, 1999.

RUSECKI, Marian. "Geneza religii.” In Leksykon Teologii Fundamentalnej [“The Genesis of Religion.” In: Lexicon of Fundamental Theology], edited by Marian Rusecki, Krzysztof Kaucha, Ireneusz S. Ledwoń, Jacenty Mastej, 431-440. Lublin-Kraków: Wydawnictwo M, 2002.

RuSECKI, Marian. Istota i geneza religii [The Essence and Genesis of Religion]. Lublin-Sandomierz: Wydawnictwo Diecezjalne, 1997.

RUSECKI, Marian. "Jeana Mouroux elementy personalistycznej koncepcji Objawienia” ["Jean Mouroux's Elements of the Personalistic Concept of Revelation"]. Roczniki Teologiczne 47, no 9 (2000): 13-29.

RUSECKI, Marian. “Objawieniowa geneza religii.” In Plenitudo legis dilectio. Księga pamiatkowa dedykowana prof. dr. hab. Bronistawowi W. Zubertowi OFM z okazji 65. rocznicy urodzin ["The Revelatory Genesis of Religion." In: Plenitudo legis dilectio. A Memorial Book Dedicated to Prof. Dr. Hab. Bronisław W. Zubert OFM on the Occasion of his $65^{\text {th }}$ Birthday], edited by Antoni Dębiński, Elżbieta Szczot, 789-799. Lublin: Wydawnictwo KUL, 2000.

RUSECKI, Marian. "Pojęcie Objawienia Bożego w religiach" ["The Concept of Divine Revelation in Religions"]. Roczniki Teologiczne 46, no 9 (1999): 13-27.

RuSECKI, Marian. Traktat o Objawieniu [Treatise on Revelation]. Krakow: Wydawnictwo Księży Sercanów, 2007.

RUSECKI, Marian. Traktat o religii [Treatise on Religion]. Warsaw: Verbinum, 2007.

RusECKI, Marian. Traktat o wiarygodności chrześcijaństwa. Dlaczego wierzyć Chrystusowi? [Treatise on the Credibility of Christianity. Why believe Christ?] Lublin: TN KUL, 2010.

Rusecki, Marian, Ireneusz S. Ledwoń, “Objawienie Boże.” In Leksykon Teologii Fundamentalnej ["Divine Revelation." In: Lexicon of Fundamental Theology], edited by Marian Rusecki, Krzysztof Kaucha, Ireneusz S. Ledwoń, Jacenty Mastej, 859-871. Lublin-Krakow: Wydawnictwo M, 2002.

SeCKLer, Max. "Il concetto di rivelazione." In Corso di teologia fondametale. 2. Trattato sulla rivelazione, edited by Walter Kern, Hermann J. Pottmeyer, Max Seckler, 66-94. Brescia: Queriniana, 1990.

TANZELlA-NitTi, Giuseppe. Teologia della credibilità. La teologia fondamentale e la sua dimensione di apologia. Roma: Città Nuova, 2015.

Translated by Jan Kobytecki

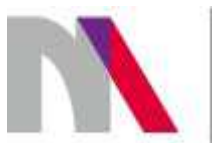

The preparation of the English version of Roczniki Teologiczne (Annals of Theology) and its publication in electronic databases was financed under contract no. 836/P-DUN/2018 from the resources of the Minister of Science and Higher Education for the popularization of science. 